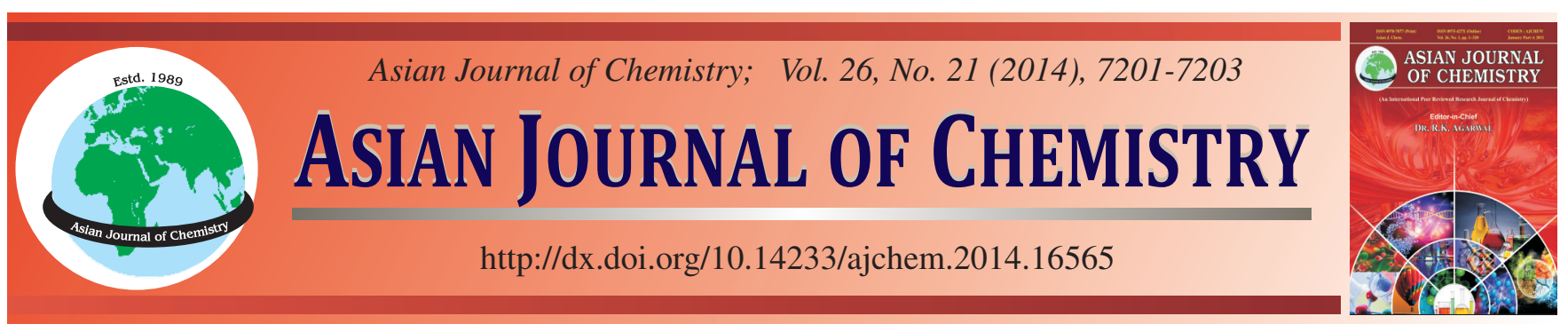

\title{
Synthesis, Crystal Structure and Spectra Properties of Cd(II) Complex with 1,5-Diamino-3-oxapentane
}

Congfen Li, Yuchen Bai, Furong Shi, Zainui Yang, Cuiping Wang and Huilu Wu*

School of Chemical and Biological Engineering, Lanzhou Jiaotong University, Lanzhou 730070, Gansu Province, P.R. China

*Corresponding author: Tel/Fax: +86 931 4938755; E-mail: wuhuilu@163.com

Received: 22 October 2013;

Accepted: 12 February 2014;

Published online: 30 September 2014;

AJC-16102

\begin{abstract}
A new complex of the cadmium(II) nitrate with 1,5-diamino-3-oxapentane (L), with the composition is $\left[\mathrm{Cd}(\mathrm{L})\left(\mathrm{NO}_{3}\right)_{2}\right]$, was synthesized and characterized by elemental analyses and IR spectra. The crystal structure of the complex has been determined by the single-crystal $\mathrm{X}$-ray diffraction. The molecular structure consists of a ligand $\mathrm{L}$, two nitrate radical and a $\mathrm{Cd}$ (II) atom. In the complex, the Cd(II) atom is $\mathrm{N}, \mathrm{O}, \mathrm{N}$-chelated by a ligand $\mathrm{L}$ and is further coordinated by two nitrate anions in a distorted monocapped octahedral geometry. The crystal structure is mainly stabilized by the intermolecular hydrogen bond.
\end{abstract}

Keywords: Crystal structure, Cadmium complex, Spectra property.

ᄂ - - - - - - - - - - - - - - -

\section{INTRODUCTION}

Various amines are extensively distributed in natural world and some of which are necessary for keeping life $\mathrm{e}^{1,2}$. Polyamines are important in biochemistry because they are present in the cells of microorganisms and animal organisms and contribute to the stabilization of the structure and activity of RNA and DNA $^{3,4}$. The amine groups have been found to be one of the most efficient functional groups for heavy metal ion removal and various adsorbents with the amine functional groups have been developed from natural biopolymers ${ }^{5-7}$.

Complexes containing polydentate amine as ligand have been widely reported in the literature ${ }^{8-13}$. Polydentate amine ligands generally coordinate to transition metal ions using all of the available nitrogen atoms as donors ${ }^{14}$. Transition metal coordination involving tridentate amines as ligands have attracted solid attention for their role as model compounds for bioinorganic systems, as building blocks in supermolecule assemblies and as catalysts ${ }^{15}$. 1,5-Diamino-3-oxapentane as one of the classics of polyamines behave as tridentate ligand that can form three coordinative bonds with a metal atom through the long pair electrons on two nitrogen and an oxygen. In this paper, we have prepared and investigated the spectral properties and crystal structure of the Cd (II) complex with the ligand of 1,5-diamino-3-oxapentane.

\section{EXPERIMENTAL}

All the starting compounds and solvents were used as commercial products of analytical grade without any purifi- cation. $\mathrm{C}, \mathrm{H}$ and $\mathrm{N}$ contents were determined using a Carlo Erba 1106 elemental analyzer. The IR spectra were recorded on the $4000-400 \mathrm{~cm}^{-1}$ region with a Nicolet FI-VER spectrometer using $\mathrm{KBr}$ pellets.

Synthesis of 3-oxapentane-1,5-diamine: 3-oxapentane1,5-diamine was synthesized by the known method ${ }^{16}$. Elemental analysis (\%): Found: C, 45.98; H, 11.50; N, 26.76. Calcd.: C, 46.25; H, 11.54; N, 26.90. Selected IR data: (KBr $\left.\mathrm{V}_{\max }, \mathrm{cm}^{-1}\right), 1120\left(\mathrm{~V}_{\mathrm{C}-\mathrm{O}-\mathrm{C}}\right), 3340\left(\mathrm{~V}_{-\mathrm{NH}_{2}}\right)$ stretching frequency, respectively.

Preparation of the $\left[\mathrm{Cd}(\mathrm{L})\left(\mathrm{NO}_{3}\right)_{2}\right]$ : To a stirred solution of $\mathrm{L}(0.104 \mathrm{~g}, 1 \mathrm{mmol})$ in $\mathrm{EtOH}(10 \mathrm{~mL})$ was added $\mathrm{Cd}\left(\mathrm{NO}_{3}\right)_{2} \cdot 4 \mathrm{H}_{2} \mathrm{O}$ $(0.308 \mathrm{~g}, 1 \mathrm{mmol})$ in EtOH $(5 \mathrm{~mL})$. A white crystalline product formed rapidly. The precipitate was filtered off, washed with EtOH and in vacuo. The dried precipitate was dissolved in DMF resulting in a colourless solution. The crystals suitable for X-ray diffraction measurement were obtained by ether diffusion into DMF after several days at room temperature. Yield: $0.115 \mathrm{~g}(28 \%)$. Elemental analysis (\%): Found: C, 14.0; H, 3.6; N, 16.5. Calcd.: C, 14.1; H, 3.5; N, 16.5.

X-Ray crystal structure determination: A suitable single crystal was mounted on a glass fiber and the intensity data were collected on a Bruker SMART APEX diffractometer with graphite-monochromated $\operatorname{MoK}_{\alpha}$ radiation $(\lambda=0.71073 \AA)$ at 296 K. Date reduction and cell refinement were performed using SAINT programs ${ }^{17}$. The absorption corrections were carried out by the empirical method. The structure was solved by direct methods and refined by full-matrix least-squares against $\mathrm{F}^{2}$ of data using SHELXTL software ${ }^{18,19}$. All $\mathrm{H}$ atoms 
were found in difference electron maps and were subsequently refined in a riding-model approximation with $\mathrm{C}-\mathrm{H}$ distances is $0.97 \AA$ and $\mathrm{U}_{\mathrm{iso}}(\mathrm{H})=1.2 \mathrm{U}_{\mathrm{eq}}(\mathrm{C})$. A summary of parameters for the data collections and refinements is given in Table- 1 .

Crystallographic data for the $\mathrm{Cd}(\mathrm{II})$ complex has been deposited with the Cambridge Crystallographic Data Center as supplementary publication No. CCDC 879804. Copies of the data can be obtained free of charge on application to The Director, CCDC, 12 Union Road, Cambridge CB2 1EZ, UK (fax: +44 1223336 033; e-mail: deposit@ccdc.cam.ac.uk).

TABLE-1

\begin{tabular}{|c|c|}
\hline \multicolumn{2}{|c|}{$\begin{array}{c}\text { TABLE-1 } \\
\text { CRYSTALLOGRAPHIC DATA AND DATA } \\
\text { COLLECTION PARAMETERS FOR }\left[\mathrm{Cd}(\mathrm{L})\left(\mathrm{NO}_{3}\right)_{2}\right]\end{array}$} \\
\hline Formula & $\mathrm{C}_{4} \mathrm{H}_{12} \mathrm{~N}_{4} \mathrm{O}_{7} \mathrm{Cd}$ \\
\hline M & 340.59 \\
\hline system & Monoclinic \\
\hline space group & $\mathrm{C} 2 / \mathrm{c}$ \\
\hline $\mathrm{a}(\AA)$ & $13.561(6)$ \\
\hline $\mathrm{b}(\AA)$ & $8.677(4)$ \\
\hline$c(\AA)$ & $10.988(8)$ \\
\hline$\beta /\left(^{\circ}\right)$ & 90 \\
\hline $\mathrm{V} / \AA^{3}$ & $126.048(4)$ \\
\hline Z & 90 \\
\hline$\rho_{\text {caled }} \mathrm{g} / \mathrm{cm}^{3}$ & 2.164 \\
\hline Limiting indices & $-13,16 /-10,10 /-13,13$ \\
\hline Crystal size mm & $0.25 \times 0.21 \times 0.19$ \\
\hline Absorption correction & Semi-empirical from equivalents \\
\hline Data/restraints/parameters & 4985 / 6 / 396 \\
\hline $\mathrm{F}(000)$ & 168 \\
\hline Final $R$ indices $[I>2 \sigma(I)]$ & $\mathrm{R}_{1}=0.0630, \mathrm{wR}_{2}=0.1871$ \\
\hline $\mathrm{R}$ indices (all data) & $\mathrm{R}_{1}=0.0632, \mathrm{wR}_{2}=0.1872$ \\
\hline$\Delta \rho(\max )$ and $\Delta \rho(\min ),\left(\mathrm{e} \AA^{-3}\right)$ & 2.495 and -2.750 \\
\hline
\end{tabular}

\section{RESULTS AND DISCUSSION}

The $\mathrm{Cd}(\mathrm{II})$ complex $\left[\mathrm{Cd}(\mathrm{L})\left(\mathrm{NO}_{3}\right)_{2}\right]$ was prepared by reaction of $\mathrm{L}$ with $\mathrm{Cd}\left(\mathrm{NO}_{3}\right)_{2} \cdot 4 \mathrm{H}_{2} \mathrm{O}$ in ethanol. It is soluble in polar aprotic solvents such as DMF, DMSO and MeCN, slightly soluble in ethanol, methanol, ethyl acetate and chloroform and insoluble in water, $\mathrm{Et}_{2} \mathrm{O}$ and petroleum ether. The elemental analysis shows that its composition is $\left[\mathrm{Cd}\left(\mathrm{C}_{4} \mathrm{H}_{12} \mathrm{~N}_{2} \mathrm{O}\right)\left(\mathrm{NO}_{3}\right)_{2}\right]$ which was confirmed by the crystal structure analysis.
IR spectra: In the free ligand L, a strong band is found at $1120 \mathrm{~cm}^{-1}$ together along with a weak band at $3340 \mathrm{~cm}^{-1}$. By analogy with the assigned bands, the former can be attributed to $v_{(\mathrm{C}-\mathrm{O}-\mathrm{C})}$, while the latter can be attributed to $\mathrm{v}_{\left(-\mathrm{NH}_{2}\right)}$. These bands were shifted to the lower frequency $c a .40 \mathrm{~cm}^{-1}$ in the complex, which implies direct coordination of the nitrogen and oxygen atom to metal ions. Information regarding possible bonding modes of the nitrate may also be obtained from the IR spectra. The bands at 1440,1329, $1062 \mathrm{~cm}^{-1}$ indicate that the nitrate groups are bidentate coordination mode ${ }^{20-22}$. The results agree with those determined by X-ray diffraction.

Crystal structure: The selected atomic distances and bond angles of complex $\left[\mathrm{Cd}(\mathrm{L})\left(\mathrm{NO}_{3}\right)_{2}\right]$ are listed in Table-2. The ORTEP structure of $\left[\mathrm{Cd}(\mathrm{L})\left(\mathrm{NO}_{3}\right)_{2}\right]$ with atom numberings is shown in Fig. 1. The molecular structure consists of a ligand $\mathrm{L}$, two nitrate radicals and a $\mathrm{Cd}$ (II) atom. The $\mathrm{Cd}$ (II) in the complex is $\mathrm{N}, \mathrm{O}, \mathrm{N}$-chelated by a $\mathrm{L}$ and four $\mathrm{O}$ atoms from two nitrate anions. The coordination geometry of the $\mathrm{Cd}$ (II) ion may be best described as distorted monocapped octahedral. The equatorial plane is occupied by N1, N1A, O3, O3A, whereas

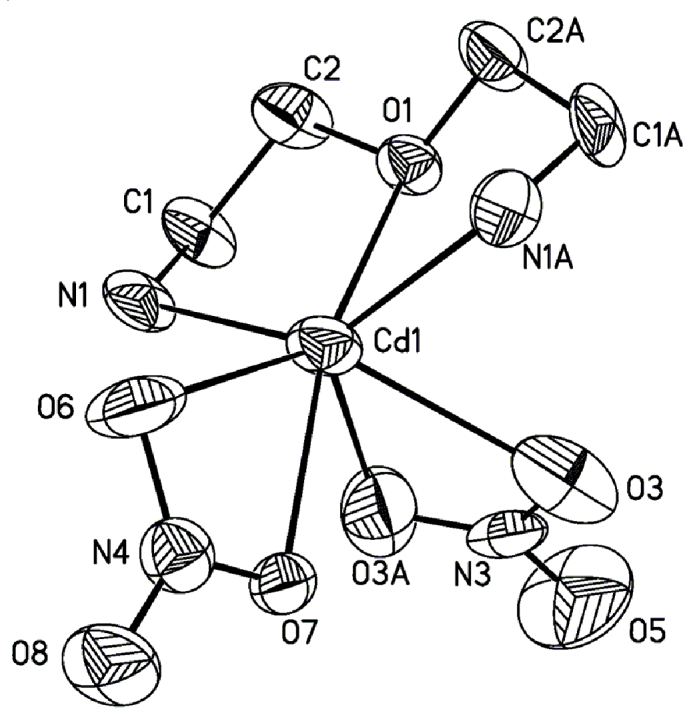

Fig. 1. Crystal structure of the complex $\left[\mathrm{Cd}(\mathrm{L})\left(\mathrm{NO}_{3}\right)_{2}\right]$. Hydrogen atoms have been omitted for clarity

\begin{tabular}{|c|c|c|c|}
\hline \multicolumn{4}{|c|}{ TABLE-2 } \\
\hline Bond distances & & & \\
\hline $\mathrm{Cd}(1)-\mathrm{N}(1) \# 1$ & $2.246(10)$ & $\mathrm{Cd}(1)-\mathrm{N}(1)$ & $2.246(10)$ \\
\hline $\mathrm{Cd}(1)-\mathrm{O}(7)$ & $2.278(10)$ & $\mathrm{Cd}(1)-\mathrm{O}(1)$ & $2.428(10)$ \\
\hline $\mathrm{Cd}(1)-\mathrm{O}(3)$ & $2.598(11)$ & $\mathrm{Cd}(1)-\mathrm{O}(3) \# 1$ & $2.598(11)$ \\
\hline $\mathrm{Cd}(1)-\mathrm{O}(6)$ & $2.608(12)$ & & \\
\hline \multicolumn{4}{|l|}{ Bond angles } \\
\hline $\mathrm{N}(1) \# 1-\mathrm{Cd}(1)-\mathrm{N}(1)$ & $138.2(5)$ & $\mathrm{N}(1) \# 1-\mathrm{Cd}(1)-\mathrm{O}(7)$ & $108.8(2)$ \\
\hline $\mathrm{N}(1)-\mathrm{Cd}(1)-\mathrm{O}(7)$ & $108.8(2)$ & $\mathrm{N}(1) \# 1-\mathrm{Cd}(1)-\mathrm{O}(1)$ & $75.0(2)$ \\
\hline $\mathrm{N}(1)-\mathrm{Cd}(1)-\mathrm{O}(1)$ & $75.0(2)$ & $\mathrm{O}(7)-\mathrm{Cd}(1)-\mathrm{O}(1)$ & $162.3(4)$ \\
\hline $\mathrm{N}(1) \# 1-\mathrm{Cd}(1)-\mathrm{O}(3)$ & $78.8(3)$ & $\mathrm{N}(1)-\mathrm{Cd}(1)-\mathrm{O}(3)$ & $125.3(3)$ \\
\hline $\mathrm{O}(7)-\mathrm{Cd}(1)-\mathrm{O}(3)$ & $80.5(3)$ & $\mathrm{O}(1)-\mathrm{Cd}(1)-\mathrm{O}(3)$ & $83.4(3)$ \\
\hline $\mathrm{N}(1) \# 1-\mathrm{Cd}(1)-\mathrm{O}(3) \# 1$ & $125.3(3)$ & $\mathrm{N}(1)-\mathrm{Cd}(1)-\mathrm{O}(3) \# 1$ & $78.8(3)$ \\
\hline $\mathrm{O}(7)-\mathrm{Cd}(1)-\mathrm{O}(3) \# 1$ & $80.5(3)$ & $\mathrm{O}(1)-\mathrm{Cd}(1)-\mathrm{O}(3) \# 1$ & $83.4(3)$ \\
\hline $\mathrm{O}(3)-\mathrm{Cd}(1)-\mathrm{O}(3) \# 1$ & $48.7(4)$ & $\mathrm{N}(1) \# 1-\mathrm{Cd}(1)-\mathrm{O}(6)$ & $94.2(3)$ \\
\hline $\mathrm{N}(1)-\mathrm{Cd}(1)-\mathrm{O}(6)$ & $94.2(3)$ & $\mathrm{O}(7)-\mathrm{Cd}(1)-\mathrm{O}(6)$ & $52.4(4)$ \\
\hline $\mathrm{O}(1)-\mathrm{Cd}(1)-\mathrm{O}(6)$ & $145.3(4)$ & $\mathrm{O}(3)-\mathrm{Cd}(1)-\mathrm{O}(6)$ & $127.5(3)$ \\
\hline $\mathrm{O}(3) \# 1-\mathrm{Cd}(1)-\mathrm{O}(6)$ & $127.5(3)$ & & \\
\hline
\end{tabular}


the $\mathrm{Cd}(\mathrm{II})$ ion protrudes towards $\mathrm{O} 5$ by $0.525 \AA$ from the plane of atoms $\mathrm{N} 1 / \mathrm{N} 1 \mathrm{~A} / \mathrm{O} 3 / \mathrm{O} 3 \mathrm{~A}$. In the case of the complex, the axial positions are occupied by the $\mathrm{O} 1$ atom and another $\mathrm{O} 7$ atom. The distance between the axial $\mathrm{O} 1$ atom and the equatorial plane is $1.891 \AA$, but the distance between the axial O7 atom and the equatorial plane is $2.618 \AA$. The bond angle of the two atoms through the metal center (O1-Cd1-O7) in axial positions is $162.3(4)^{\circ}$. The capping atom, O6, lies 1.974 $\AA$ out of the N1/N1A/O7 trigonal plane ${ }^{23}$.

$\mathrm{NH}$...O hydrogen-bonding interactions play important roles in the crystal packing modes in the complex (Fig. 2). The selected hydrogen bonds are listed in Table-2. The introductions of $\mathrm{NH}_{2}$ groups in the frameworks successfully lead to the assembly of these monomeric units by intermolecular hydrogen bonds. As illustrated in Fig. 2, one of the terminal hydrogen of the $\mathrm{N}$ atom of the ligand is bound to one of the oxygen atom of the nitrate radical, in which the two monomers are nearly in the same plane and these interactions afford a three-dimensional network structure of $\left[\mathrm{Cd}(\mathrm{L})\left(\mathrm{NO}_{3}\right)_{2}\right]_{\mathrm{n}}$.

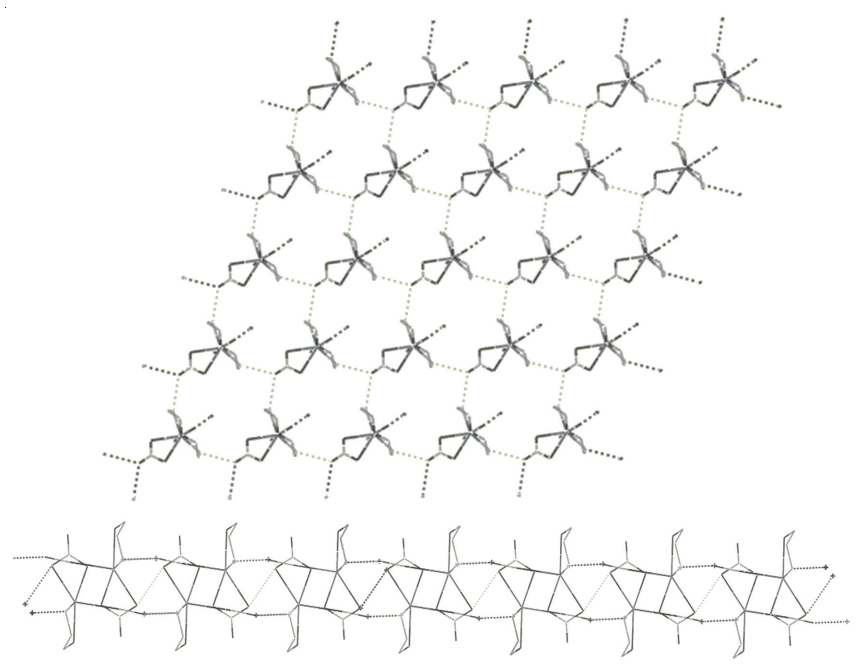

Fig. 2. View of N-H-O hydrogen bonds interaction in the complex

\section{Conclusion}

In summary, 1,5-diamino-3-oxapentane and its $\mathrm{Cd}(\mathrm{II})$ complex were synthesized and characterized based on X-ray diffraction and other structural methods. The coordination geometry can be described as distorted monocapped octahedral. The complex is mainly stabilized by the intermolecular hydrogen bond. The three intermolecular $\mathrm{NH}$...O hydrogen bonds, interlink the three adjacent units into a threedimensional network.

\section{ACKNOWLEDGEMENTS}

The present research was supported by the National Natural Science Foundation of China (Grant No. 21367017), the Fundamental Research Funds for the Gansu Province Universities (212086), National Natural Science Foundation of Gansu Province (Grant No. 1212RJZA037) and 'Qing Lan' Talent Engineering Funds for Lanzhou Jiaotong University.

\section{REFERENCES}

1. T.W.G. Solomons and C.B. Fryhle, Organic Chemistry, John Wiley \& Sons, Inc., New York, edn. 10, Ch. 20, p. 1024 (2010).

2. L.H. Zhang, X.Q. Li, Y.S. Zhou and X. Wang, J. Mol. Struct., 928, 59 (2009).

3. A. De Robertis, C. Foti, O. Giuffrè and S. Sammartano, J. Chem. Eng. Data, 46, 1425 (2001).

4. N.G. Tsierkezos, D. Schröder and H. Schwarz, Int. J. Mass Spectrom., 235, 33 (2004).

5. S. Deng, R.B. Bai and J.P. Chen, Langmuir, 19, 5058 (2003).

6. N. Li and R.B. Bai, Ind. Eng. Chem. Res., 44, 6692 (2005).

7. C.K. Liu, R.B. Bai and L. Hong, J. Colloid Interf. Sci., 303, 99 (2006).

8. C. Lodeiro and F. Pina, Coord. Chem. Rev., 253, 1353 (2009).

9. M.T. Oms, R. Forteza, V. Cerda and F. Borrull, Thermochim. Acta, 138, 1 (1989).

10. J.N. Jolley, A.I. Yanovsky, L.R. Kelland and K.B. Nolan, J. Inorg. Biochem., 83, 91 (2001).

11. M.W. Ndinguri, F.R. Fronczek, P.A. Marzilli, W.E. Crowe, R.P. Hammer and L.G. Marzilli, Inorg. Chim. Acta, 363, 1796 (2010).

12. W. Shen, S.Y. Chen, S.K. Shi, X. Li, X. Zhang, W.L. Hu and H.P. Wang, Carbohydr. Polym., 75, 110 (2009).

13. S.I. Ali and K. Majid, Thermochim. Acta, 317, 141 (1998).

14. R.L. Fanshawe, A. Mobinikhaledi, C.R. Clark and A.G. Blackman, Inorg. Chim. Acta, 307, 26 (2000).

15. P.C. Junk and J.W. Steed, Inorg. Chim. Acta, 360, 1661 (2007).

16. S.M. Nelson and C.V. Knox, J. Chem. Dalton Transac., 2525 (1983).

17. Bruker, SAINT and SMART, Bruker AXS Inc., Madison, Wisconsin, USA (2001).

18. G.M. Sheldrick, SADABS. University of Göttingen, Germany (2001).

19. G.M. Sheldrick, Acta Crystallogr. A, 64, 112 (2008).

20. K. Nakamoto, Infrared and Raman Spectra of Inorganic and Coordination Compounds, John Wiley \& Sons, New York, edn 4, p. 284 (1986).

21. W.K. Dong, Y.X. Sun, C.Y. Zhao, X.Y. Dong and L. Xu, Polyhedron, 29, 2087 (2010).

22. W.-K. Dong, J.-G. Duan, Y.-H. Guan, J.-Y. Shi and C.-Y. Zhao, Inorg. Chim. Acta, 362, 1129 (2009).

23. D.H. Kang, J.B. Seo, S.Y. Lee, J.Y. Lee, K.S. Choi and S.S. Lee, Inorg. Chem. Commun., 10, 1425 (2007). 